\title{
Construction of Special Program of Artificial Intelligence in Applied Universities of Finance and Economics
}

\author{
Linge Wang* \\ College of Digital Technology and Engineering, Ningbo University of Finance \& Economics, \\ Haishu,Ningbo,China \\ *Corresponding author.
}

\begin{abstract}
The development of AI technology has affected all walks of life in society, and then brought about the urgent demand for intelligent, compound and applied talents. Through the analysis of the current financial industry, finance and other industries, combined with the current situation of compound talent training in Financial Colleges and universities, the construction path of the "AI" special program in financial application colleges and universities is proposed, and the specific implementation plan of the course construction is described from the education objectives, curriculum objectives, teaching objectives, teaching plans and other aspects.
\end{abstract}

Keywords: AI, finance and economics, course construction, application type

\section{Introduction}

Artificial Intelligence (AI) is a technology that can be widely applied and continuously innovated in various sectors of the national economy, which means that the economic society has a huge demand for AI, because it can have a subversive impact on other industries, accelerate the technological innovation, business model and business mode changes in the industry, increase production efficiency and improve user experience. The development of AI technology has also changed the demand for talents. It is a new direction for the comprehensive reform of talent training in applied universities to carry out all-round talent training reform by using AI technology, especially how to cultivate applied talents who can adapt to the AI era, explore the new talent training mode of "AI $+\mathrm{X}$ ", and promote the application of AI technology in talent training in all walks of life.Therefore, the construction of interdisciplinary professional courses with interdisciplinary integration is of great practical significance for financial colleges and universities to create new characteristics of finance and economics, embody the multi-disciplinary characteristics of the school, enrich the knowledge structure of students, and improve students' interdisciplinary thinking and their professional competitiveness.

\section{Status Analysis}

2.1Current situation of intelligent development in financial industry

As the main front for employment of financial and economic colleges is the financial industry, whose intelligence evolution has advanced from the initial weak AI, such as the use of ATM machines, to the strong AI, such as the popularization and use of robots from the perspective of technology. As a highly data-based industry, the financial industry has a large database accumulated over the years, namely, various types of financial transactions, customer information, market analysis, risk control, investment advisers, asset allocation and their returns, etc., which has become the basis of intelligent applications. These data have huge capacity and diverse forms, and are difficult to be effectively used when the data algorithms and computational power are limited. However, with the artificial application, these data can be effectively converted into analyzable data, which can be applied in various fields such as behavior recognition, quantitative operation, enterprise credit reporting, risk analysis, etc., which to a large extent determines that the financial industry has become the easiest industry for $\mathrm{AI}^{[1]}$.

ISSN: 0010-8189

(C) CONVERTER 2021

www.converter-magazine.info 
2.2 Current situation of finance and economics talents training in finance and economics colleges

The economic majors of Shanghai University of Finance and Economics, Dongbei University of Finance and Economics and Renmin University of China were investigated to analyze the current situation of finance and economics talents training in combination with local universities such as Zhejiang University of Finance and Economics and Zhejiang Gongshang University.Shanghai University of Finance and Economics has set up machine learning and other related courses in economics majors, which started earlier, but no AI related courses have been found in accounting majors; Dongbei University of Finance and Economics does not focus on AI related courses in the training of financial talents.Looking up the training programs of economics majors in Renmin University of China (cameralistics, taxation, financial engineering, finance, credit management, insurance, finance-mathematics experiment classes, fiscal and taxation experiment classes, economics, international economics and trade, national economic management, energy economy, and economics-mathematics experiment classes), it is found that AI has not been introduced into other majors except the experimental classes, which emphasize more mathematical methods. The survey shows that most universities in China have not set up courses related to $\mathrm{AI}$ in the training plan of business talents, while some universities only set up related general courses.After analyzing the training scheme of economic talents for local application-oriented undergraduates in Zhejiang Province, it is found that no interdisciplinary professional AI course module is set up. Therefore, the construction of "AI" course in colleges of finance and economics needs to be strengthened.

\section{Construction Path of AI Special Program in Financial and Economic Applied Undergraduate Universities}

3.1Construction of interdisciplinary professional optional courses in the field of AI for finance and economics majors

For students majoring in accounting, finance, and economics and management, an interdisciplinary optional course in the field of AI should be constructed in the background of big data era. The rapid development in the field of AI has a huge and far-reaching impact on accounting, economic management, finance, insurance and other industries, because some repetitive work will gradually disappear in the near future, and it is extremely urgent to improve the knowledge and skills in the field of AI for talents in financial colleges and universities. Therefore, it is necessary to teach the knowledge in the field of AI to financial students in advance ${ }^{[2]}$. Targeted courses in the field of AI are offered for students of different majors in financial and economic colleges. The courses are constructed from three levels: foundation, technology and application, in which foundation and technology can be used as the general part of students majoring in finance and economics, while in the application level, specific cases and scenes should be selected according to the characteristics of different professional directions. By constructing two modules, the basic part and the technical part, the general education module of interdisciplinary elective courses for finance and economics majors is formed. In addition, several parallel application modules (set as X) are constructed for different financial and economics majors, and finally a " $1+1+X "$ type interdisciplinary optional course module group will be formed. For different majors, the course of "AI" is formed by combining X modules.

\subsection{Technical research of financial and economic majors in the field of AI}

The premise of ensuring the high-quality construction and standardization of courses is the right direction. Therefore, it is necessary to seriously and scientifically investigate the knowledge and skills requirements of enterprises for students majoring in finance and economics in the field of AI. At the same time, research reports should be formed to construct application scenarios for accounting, economic management, finance and other professional directions, and teaching cases should be investigated or designed for the application scenarios ${ }^{[3]}$, so that the course content can meet the knowledge demand for new financial talents in the field of AI. The knowledge system is constructed through investigation, which will provide a strong support for the construction of interdisciplinary professional optional courses and a basis for the standardized design of multiple modules in the course.

ISSN: 0010-8189

(C) CONVERTER 2021

www.converter-magazine.info 
3.3 Distinguishing the teaching emphasis of AI technology course between financial talents and engineering talents under the background of big data

The starting points and laws of learning AI are different for financial and engineering students due to the differences in knowledge background and thinking characteristics.Engineering students are easy to get started, but they are weak in finding application scenarios. Financial and economic students have strong professional knowledge, but they are slow to master some technologies.Ideally, the two should work together or finance experts lead engineering experts. However, judging from the current situation, it is very difficult for students majoring in traditional finance and economics to have such leadership.Finance and economics students learn AI not to replace engineering students, but to be the master of controlling machines, who has good expertise and an understanding of the basic logic of programming and is able to integrate AI's framework with theprofessional knowledge.

\section{The Implementation Plan for the Construction of the Special Program of AI Applied Universities of Finance and Economics}

Based on the characteristics of the high-speed development of $\mathrm{AI}$ and the new requirements for new financial talents, and in combination with the knowledge structure of non-computer professional systems, the course construction of AI is completed among interdisciplinary students according to the following ideas: Weakening the content of higher-order mathematics in AI; strengthening the auxiliary role of AI courses for non-financial majors, with emphasis on data analysis, application and decision-making; focusing on cultivating students' ability to analyze and solve problems; introducing the basic knowledge and development process of AI based on the nature of popular science; selecting algorithms that are not mathematically strong but are widely used in daily life as the focus, such as K-nearest neighbor algorithm; introducing in detail the application and prospect of AI in different fields such as management, accounting and finance ${ }^{[4]}$. In the following, the course objectives, teaching contents, teaching design and methods, and teaching evaluation are described:

\subsection{Course objectives}

By exploring the new engineering technology problems faced by the AI after it is integrated into the new finance and business, it helps students understand the new engineering technology ability in the intelligent transformation of enterprises and enhance students' competence for the enterprise engineering technology needs in the era of AI. Specifically, the integrated theory of "AI+New Finance/New Business" is applied to the classroom education of undergraduates.

This is a new teaching model that focuses on students' learning and solves complex problems through dialogue between teachers and students. On the one hand, the current academic discussion in the frontier field of AI and new finance/new business is limited, and a stable knowledge system has not been formed for undergraduate teaching. On the other hand, in the practice of enterprises, AI has begun to be applied in new finance/new business, so they are facing practical engineering and technical problems in the intelligent transformation. One of the main issues should therefore be chosen as the main line of teaching in this curriculum, whereby teachers and students are drawn together to solve the problems. But the most important thing is to make students the subject of problem-solving, in the form of a team, with the cooperation of external resources, to complete the solution to an actual problem, as "learning by doing" is an important feature of the teaching link in the course construction.

\subsection{Teaching contents}

The design of teaching content depends on the structure of AI industry chain to extract and refine AI knowledge and technology of Finance and economics. Through preliminary research on relevant industries and communication with managers and technical staff of some enterprises, it is finally determined that the overall teaching content is set around AI technology applied in enterprise engineering. Specifically, centering on AI and engineering technology in the enterprise, the design of the following teaching modules can be referred to, and then

ISSN: 0010-8189

(C) CONVERTER 2021

www.converter-magazine.info 
the course is constructed according to the course modules, the contents of which are shown in Fig. 1:

\begin{tabular}{|c|c|c|}
\hline \multicolumn{3}{|l|}{ Course modules } \\
\hline & & The four le \\
\hline \multirow{4}{*}{$\begin{array}{l}\text { The value of the } \\
\text { artificial intelligence - } \\
\text { application cases }\end{array}$} & $\begin{array}{c}\text { Intelligent recommendation application cases for } \\
\text { restaurants and movies }\end{array}$ & Handwritten Numbers Recognition \\
\hline & Predict lego set price case & Customer value analysis of airlines \\
\hline & Accurate advertising & Financial revenue forecast and analysis \\
\hline & $\begin{array}{l}\text { Mining association rules based on voting } \\
\text { records }\end{array}$ & $\begin{array}{l}\text { water heater user behavior analysis and event } \\
\text { recognition }\end{array}$ \\
\hline \multirow{5}{*}{$\begin{array}{l}\text { The core of artificial } \\
\text { intelligence- Common } \\
\text { algorithms }\end{array}$} & Bayesian classifier design & $\mathrm{k}$-means clustering \\
\hline & Discriminant function classifier & Data clustering ( $\mathrm{K}$ - means) \\
\hline & Fisher classifier & Neural network clustering \\
\hline & Data clustering & $\begin{array}{l}\text { Clustering design of simulated annealing } \\
\text { algorithm }\end{array}$ \\
\hline & Genetic Algorithm for Clustering & SVD algorithm, etc \\
\hline \multirow{3}{*}{$\begin{array}{c}\text { Basic principles of } \\
\text { artificial intelligence } \\
\text { Data acquisition and } \\
\text { processing }\end{array}$} & python-web crawler & Simulation of automatic login \\
\hline & Smart and Simple Web Crawler & Data visualization \\
\hline & craw1 dynamic web with api ur1 & $\begin{array}{l}\text { statistical analysis a } \mathrm{n} \mathrm{d} \text { numerical } \\
\text { calculation, etc }\end{array}$ \\
\hline \multirow{3}{*}{$\begin{array}{c}\text { Basic theory of } \\
\text { artificial intelligence } \\
\text { and Industry trend in } \\
\text { Enterprise } \\
\text { Engineering }\end{array}$} & $\begin{array}{l}\text { Research and application of artificial } \\
\text { intelligence }\end{array}$ & $\begin{array}{l}\text { Basic principles of artificial intelligence } \\
\text { research }\end{array}$ \\
\hline & Development of artificial intelligence research & $\begin{array}{l}\text { The development prospect of artificial } \\
\text { intelligence research }\end{array}$ \\
\hline & Achievements of artificial intelligence research & $\begin{array}{l}\text { Engineering technology prospect of artificial } \\
\text { intelligence technology in Enterprises }\end{array}$ \\
\hline
\end{tabular}

\section{Fig. 1 Composition of course module}

4.3Teaching design and methods

4.3.1. Inquiry-based teaching

In teaching, the teaching content should be set up around the engineering and technical problems in enterprises, combined with the characteristics of students of interdisciplinary specialties, and the teaching process management should be carried out. Engineering technology problems in enterprises can better reflect the process of discovering problems $\rightarrow$ raising problems $\rightarrow$ analyzing problems $\rightarrow$ solving problems. At the same time, it is also a common concern of enterprises at present. Inquiry-based teaching can mobilize resources from all sides through sufficient dialogue between teachers and students to support the student-centered learning process.

ISSN: 0010-8189 
4.3.2. Learning by doing

All students are required to practice, because some algorithms of AI technology need to be practiced by themselves, which can realize the process without programming, and can extrapolate the algorithm step by step like a business model. Therefore, instead of being an armchair strategist, it is not necessary to apply these technologies in practice, and let students think about classroom teaching contents in real scenarios ${ }^{[5]}$.

\subsubsection{Case teaching}

Some cases suitable for finance class and business class related cases are selected for teaching, so as to improve the students' ability to apply AI technology to increase the engineering application ability, so that the engineering ability can be a beneficial supplement to students in finance class.

\subsection{Teaching evaluation}

Teaching evaluation is carried out iteratively, i.e. the course scores are distributed in each module, and each module has a test bank, including theoretical and practical contents. Within the period of time after completion of the module's teaching contents, students complete the test iteratively and repeatedly. The content of each test is randomly selected from the question bank. According to the content of the question bank, students are given several opportunities to score in stages or set different weights of different times. Their stage achievements are determined according to the formula and finally summarized for continuous training, continuous testing, continuous improvement and continuous approaching to the teaching objectives. In the evaluation process, attendance and classroom performance, discussion, practice and research report (in the form of final examination) are taken as the main evaluation criteria.

\section{Conclusions}

Under the background of big data, the development of AI puts forward new requirements for financial professionals such as accounting, finance, insurance, and economic management, and poses new challenges to the training of new business professionals. The management ability, analysis ability, decision-making ability, and leadership ability of financial professionals are further defined. By constructing the special program of "AI", the comprehensive ability of financial professionals will be improved, and the quality of personnel training will be further improved.

\section{Acknowledgements}

Supported by the Second Batch of Teaching Reform Programs of Higher Education in Zhejiang Province During the 13th Five-Year Plan Period (jg20190514), Key Teaching Reform Program of Ningbo University of Finance and Economics (<Artificial Intelligence Foundation>Cross-Specialized Optional Course Construction Project).

\section{References}

[1] H.M. Chen, Y.B. Xu, Y.H. Li, “Artificial intelligence and talent training of economics specialties in local application-oriented undergraduate institutes,” Journal of Beijing city university, no. 1, 2019.

[2] M. Zhang, "Artificial intelligence and application in finance,” IC4E 2020: 2020 the 11th International Conference on E-Education, E-Business, E-Management, and E-Learning. 2020.

[3] T. Moloi, T. Marwala, "Introduction to artificial intelligence in economics and finance theories," 2020.

[4] A.J.W.V.D.Gevel, C.N. Noussair,"The nexus between artificial intelligence and economics," Social Science Electronic Publishing, 2012-087:1-110, 2013.

[5] Dirican, Cüneyt, "The impacts of robotics, artificial intelligence on business and economics," Procedia Social \& Behavioral Sciences, vol. 195, pp. 564-573, 2015. 